which is, to what should be everybody's surprise, fixed not by universities but by the government (which repeatedly adjusts it up when it wishes to augment universities' sense of freedom and down, as in 1981, when it wishes to cramp them in). What would now best suit the universities is an understanding that they should be free to charge what tuition fees they choose, and that they should keep what they collect. Ideally, the fees asked of students should be related to the marginal cost of education (and not to the average, which must be substantially greater), but if the years ahead may see some universities hard pressed to find students, they may need the freedom to charge what the market will bear.

The question of whether governments should, in principle, pay the cost of maintaining students in higher education is more complicated, and goes back to the report of the Robbins committee which, in 1963, launched the expansion of the British university system with the doctrine that access should be open to all schoolleavers who are qualified to take advantage of it. Especially because so many of the new British universities are sited miles away from their catchment areas, the assumption has grown up that students will ordinarily travel to some distant place if they enter higher education, and successive governments have found themselves embroiled in tedious arguments with the National Union of Students over the proper level of the "travel grant" by which the ordinary maintenance grant is supplemented. One consequence, from which the British university system as a whole has suffered, is the erosion of the regional connections of universities such as the red-brick creations of the nineteenth century. It would not be a serious setback for the British system if the principle were now followed that student maintenance should not be a public charge. To protect universities that are vulnerable because of their geographical isolation, there would no doubt have to be a transitional arrangement of some kind.

Outside Britain, it is bound to seem strange that the provision of grants to students is a serious issue. Almost everywhere, students are constrained in their choice of higher education establishments by the costs not merely of tuition but of maintaining themselves independently. Can Britain, with its perpetual money troubles, afford to be different?

One practical consequence of such a move towards economic realism would be serious hardship among students, many of whom already live in too much squalor, perhaps waiting for parental contributions that do not materialize. Moreover, British students are less able than those elsewhere to earn money to help with their costs, partly because of the economic climate but also because of trade union restrictions, while most universities have no significant endowment funds with which to help able people in trouble. That is why British policy on students can be transformed to what it should be only by equipping universities financially to be able to do their duty to their students.

The problem of students from poor homes is different, serious but soluble. Entry to British higher education is still skewed against the children of the less well off, with the consequence that too little is made of the national pool of talent. The needs of these potential students are theoretically catered for by the present system of maintenance grants but, as the figures show, the outcome is inadequate. The simple remedy is to replace the present system by one of scholarships awarded to able schoolleavers and others which, at their most generous, would cover not merely the bare cost of maintenance but some part of the opportunity cost of higher education (the wages forgone), but which would be tenable anywhere, not simply at the institution that happens to offer a student a place. Beyond the resoloution of that problem there are other conundrums to be tackled. Slowly, in the past few years, British governments and universities have awakened to the need and opportunity for using existing educational plant for training persons of mature years, many of them already in jobs. But there are at present only disincentives (tuition fees out of taxed income, for example) to its efficient use. That is also a problem that needs solving. If the trouble Sir Keith Joseph has brought down on his government's head should have the effect of spurring a search for better ways of enlarging participation in higher education, it may yet be worth while.

\section{Japanese uncreativity}

Japan's new strategy for research is more a recipe for continued success than for creativity.

JAPAN's obsession with creativity is a curious phenomenon. Merely moderately successful nations are usually distinguished by their complacency. Japan, by contrast, after three decades of spectacular economic success, seems perpetually down in the dumps, with its conviction that Japanese technology is in reality derivative, and that its gigantic technical effort lacks creative flair. Is it possible that Japan's competitors in the West, beaten onto the ropes though they may be the technical achievements of Japanese industry, have been able to ensure that Japan does not fully enjoy its success by suggesting that there is something missing?

The point has been endlessly discussed in Japan in the past five years, but will not be settled with the publication this week (see facing page) of the blueprint for future research drawn up by the Council for Science and Technology in Tokyo. There is a grain of truth in the common Japanese assumption that many of the products with which Japan has swept the world are derived from machines already built elsewhere. But so what? From ships to video-recorders, Japanese technologists have been able to design and manufacture high-quality products more cheaply than others, and at the same time make sure that they function reliably. If the ingenuity is not creative, many technologists elsewhere will be wondering what is meant by creativity.

The more substantial sense in which Japan is technically uncreative is in the contribution of the university system to basic science, but the reasons are now familiar. First, the rigidity of the academic institutions, and the parsimony with which they are supported, drives energetic academics into applied science and into partnerships with industry. Second, students march predominantly into the academic engineering departments. Righting this imbalance would require long-due changes in the academic structure, which the science and technology council has plainly considered outside its terms of reference. Indeed, the list of objectives accompanying this week's strategic plan is not so much a recipe for creativity as a shopping list for tomorrow's high technology that could be found in most other places in the West. To be sure, Japan may succeed where others fail, but that is a very different matter.

\section{Damming the water}

\section{Are the British and French governments losing an opportunity?}

WHAT follows is not a joke. For at least two hundred years, but at different times, the English and the French have been suggesting proposals for a permanent link across the 21 miles of water that separate them. Most schemes have turned on the construction of a tunnel. In the 1960s, bridges briefly became fashionable. Now, the favoured way of spanning the Channel is to build a composite structure, part bridge and part tunnel. To judge from the AngloFrench meeting in Paris last week, the remaining obstacles to a permanent link are merely legal and financial.

Nobody, however, has seriously considered what must be the most obvious way of spanning this narrow and shallow stretch of water, the building of a permanent dam across the Channel. The advantages are obvious (see Nature 219,$991 ; 1968$ ). It would be possible to generate endless electricity, the Dutch would no longer have to worry about their dykes and it would be possible to walk across, as at the glacial maximum 18,000 years ago. The disadvantages are few, the most obvious of them being the disturbance caused to shipping, most of which could just as well go round the north of Scotland. The cost of such a project has never been determined, but could well turn out to be surprisingly small. Although megaprojects are now out of fashion, should not the British and French governments look seriously at this ideal before committing themselves to a clumsier alternative? 